\title{
Fluid Dynamics of Pressurized, Entrained Coal Gasifiers
}

\author{
Quarterly Report \\ April 1 - June 30, 1997
}

Work Performed Under Contract No.: DE-FG22-93PC93216

\author{
For \\ U.S. Department of Energy \\ Office of Fossil Energy \\ Federal Energy Technology Center \\ P.O. Box 880 \\ Morgantown, West Virginia 26507-0880
}

By

Cornell University

Sibley School of Mechanical \& Aerospace Engineering

Upson Hall

Ithaca, New York 14853 


\section{Disclaimer}

This report was prepared as an account of work sponsored by an agency of the United States Government. Neither the United States Government nor any agency thereof, nor any of their employees, makes any warranty, express or implied, or assumes any legal liability or responsibility for the accuracy, completeness, or usefulness of any information, apparatus, product, or process disclosed, or represents that its use would not infringe privately owned rights. Reference herein to any specific commercial product, process, or service by trade

name, trademark, manufacturer, or otherwise does not necessarily constitute or imply its endorsement, recommendation, or favoring by the United States Government or any agency thereof. The views and opinions of authors expressed herein do not necessarily state or reflect those of the United States Government or any agency thereof. 


\begin{abstract}
$\underline{\text { Abstract }}$
Pressurized, entrained gasification is a promising new technology for the clean and efficient combustion of coal. Its principle is to operate a coal gasifier at a high inlet gas velocity to increase the inflow of reactants, and at an elevated pressure to raise the overall efficiency of the process. Unfortunately, because of the extraordinary difficulties involved in performing measurements in hot, pressurized, high-velocity pilot plants, its fluid dynamics are largely unknown. Thus the designer cannot predict with certainty crucial phenomena like erosion, heat transfer and solid capture.

In this context, we are conducting a study of the fluid dynamics of Pressurized Entrained Coal Gasifiers (PECGs). The idea is to simulate the flows in generic industrial PECGs using dimensional similitude. To this end, we employ a unique entrained gas-solid flow facility with the flexibility to recycle -rather than discard-gases other than air. By matching five dimensionless parameters, suspensions in mixtures of helium, carbon dioxide and sulfur hexafluoride simulate the effects of pressure and scale-up on the fluid dynamics of PECGs. Because it operates under cold, atmospheric conditions, the laboratory facility is ideal for detailed measurements.

These activities are conducted with Air Products \& Chemicals, Inc., which is a member of a consortium that includes Foster Wheeler and Deutsche Babcock Energie- und Umwelttechnik AG.
\end{abstract}

\title{
Table of Contents
}

Title page $\quad 1$

Disclaimer 2

Abstract 3

Table of Contents $\quad 3$

Progress 4 


\section{$\underline{\text { Progress }}$}

In the fifteenth quarter of this project, we have completed all experiments related to this project and have begun to correlate the results for "atmospheric" and "pressurized" flows. In particular, by comparing these results with those of earlier "pressurized" experiments at a different value of $\mathrm{Ar}$, we have found that the parameter $\mathrm{K}$ introduced in previous quarterly reports scales as

$\kappa \approx 1.25 \frac{\left(1-\frac{1}{\mathrm{R}}\right) \sqrt{\mathrm{R} \mathrm{Ar}}}{18 \mathrm{Fr}}$.

In this case, the gas voidage $\varepsilon$ in the upper, nearly fully-developed region of a CFB riser, whether running under atmospheric or pressurized conditions, is reasonably predicted by the following Eq:

$(1-\varepsilon) \varepsilon^{2}=1.25\left[(\alpha-1)+(1-\varepsilon)\left(1+\frac{M}{R}\right)-\frac{M}{R}\right]$,

where $\alpha \approx 1.00035$ is a parameter expressing the correlation between the radial profiles of gas velocity and voidage, $\mathrm{M}$ is the solid loading and $\mathrm{R}$ is the solid-to-gas density ratio.

Our intention for the next quarter is to write the final report for this project. 